\title{
HAK ASASI MANUSIA (HAM) PERSPEKTIF AL-QUR'AN (Analisis Maqâshid asy-Syarî’ah dengan Pendekatan Tafsir)
}

Jufri Hasani Z

Institut Agama Islam Negeri Takengon, Aceh, Indonesia E-mail:

hasanijufri3@gmail.com
Abstract: Humans as noble creatures have rights that must be given by various parties. Oppression, colonization and slavery and discrimination are forms of action that do not respect human rights. The sentence "Colonialism over the world must be abolished" contained in the preamble of the 1945 Constitution emphasizes how human dignity and freedom must not be taken away. This paper tries to reveal Human Rights (HAM) from the perspective of the Qur'an by using the maqâshid as-syarî'ah concept as the scalpel. Discussions about human rights in the world have emerged since the 18th century ago, while the formulation of human rights that are considered legal and standardized today is that published by the United Nations Agency, which was declared on December 10, 1948 and later. known as "The Universal Declaration of Human Rights". The struggle for human rights is increasing considering the condition of human rights violations that occur in many parts of the world. In Islam, through the signs of the Qur'an, general rules related to human rights are found, including: 1) the right to life; 2) the right to education; 3) the right to freedom and protection of property; 4) the right to honor and; 5) religious rights. This research is in the form of library research using thematic interpretation methods based on themes using the maqâshid ash-syarî'ah approach.

\begin{abstract}
Abstrak: Manusia sebagai makhluk yang mulia memiliki hak yang mesti diberikan oleh berbagai pihak. Penindasan, penjajahan dan perbudakan serta sikap diskriminasi merupakan bentuk tindakan yang tidak menghargai hak manusia. Adanya kalimat "Penjajahan di atas dunia harus dihapuskan" yang terdapat pada pembukaan UUD 1945 mempertegas betapa kemuliaan dan kemerdekaan manusia tidak boleh dirampas. Tulisan ini mencoba mengungkap Hak Asasi Manusia (HAM) perspektif al-Qur'an dengan menjadikan konsep maqâshid as-syarî'ah sebagai pisau bedahnya. Perbincangan tentang HAM di dunia sudah muncul sejak abad ke $18 \mathrm{M}$ yang lalu, sementara rumusan tentang hak hakhak asasi manusia yang dianggap legal dan dijadikan standar pada saat ini adalah yang diterbitkan oleh Badan Perserikatan BangsaBangsa, yang dideklarisakan pada 10 Desember 1948 dan lebih dikenal dengan "The Universal Declaration Of Human Rights". Perjuangan HAM semakin meningkat melihat kondisi pelanggaran HAM yang banyak terjadi di berbagai belahan dunia. Dalam Islam, melalui isyarat al-Qur'an ditemukan aturan umum terkait HAM, di antaranya: 1) hak untuk hidup; 2) hak untuk mendapatkan pendidikan; 3) hak kebebasan dan perlindungan harta; 4) hak atas kehormatan dan; 5) hak beragama. Penelitian ini berbentuk library research (Penelitian Kepustakaan) menggunakan metode tafsir tematik berdasarkan tema menggunakan pendekatan maqâshid asy-syarî'ah.
\end{abstract}

Kata Kunci: HAM, Perpektif, al-Qur'an, Maqâshid asy-Syarî'ah 


\section{PENDAHULUAN}

Perbincangan mengenai Hak Asasi Manusia (HAM) selalu menarik perhatian diberbagai kalangan. Istilah hak asasi manusia dalam bahasa Arab populer dengan huqûq al-insân dan dalam bahasa Turki dengan hukuklari (John L. Esposito, 2002). Manusia sebagai makhluk yang mulia memiliki hak-hak yang mesti mereka dapatkan. Pengakuan tentang "kemanusiaannya" adalah sesuatu yang teramat mahal untuk diabaikan.HAM dikembangkan oleh pemikir di Eropa antara lain oleh Jhon Locke(m. 1704), Rousseau (m. 1778), Thomas Hobbes (m. 1679), dan Montesquieu (m. 1755) yang dipicu oleh sistem pemerintah di Eropa waktu itu yang rata-rata diktator otoriter. Untuk menumbangkan sistem tersebut, dikembangkannya ide individualisme yang sampai sekarang dianggap sebagai salah satu ciri manusia Barat. Individu dalam arti positif, kemandirian, perlu dikembangkan. Sedangkan dalam arti negatif, egoistik, harus ditinggalkan (A. Masyhur Efendi, 1994).

Masyarakat dunia pada abad ke-18 Masehi mulai membuka diri untuk mengkaji dan merumuskan undangundang yang akan mengayomi terpeliharanya hak-hak manusiameski secara resmi HAM baru dimaklumkan secara resmi sebagai ungkapan persatuan seluruh manusia pada tanggal 10 Desember 1948. Sejak itu, setiap negara yang ingin bergabung dengan PBB harus memperhitungkan, bahwa tindakannya secara internasional diukur antara lain dari pelaksanaan HAM. Namun maksud utama pemakluman HAM antara lain untuk mengatasi perbedaan antara pemeluk agama yang satu dengan agama lain (Mardiniah, 2000).
Hak Asasi Manusia (HAM) merupakan suatu konsep etika politik modern dengan gagasan pokok penghargaan terhadap manusia dan kemanusiaan. Gagasan ini membawa kepada sebuah tuntutan moral tentang bagaimana seharusnya manusia memperlakukan sesama manusia. Tuntutan moral tersebut,sejatinya merupakan ajaran inti semua agama. Sebab, semua agama mengajarkan pentingnya penghargaan dan penghormatan terhadap manusia. Tuntutan moral diperlukan untuk melindungi seseorang atau kelompok yang lemah (al-musthad'afin) dari tindakan zalim dan semena-mena yang biasanya datang dari mereka yang kuat dan berkuasa (Musdah Mulia, 2010).

Akhmad Jengis menyatakan bahwa pada tahun 1215 Inggris telah memiliki Magna Carta yang isinya antara lain memuat prinsip untuk membatasi kekuasaan pemerintah demi kepentingan hak dan kebebasan warga negara. Tahun 1639, Inggris menghasilkan "English Bill of Right" yang dijadikan landasan konstitusional pemerintahannya. Pengalaman Inggris ini menginspirasi Amerika sehingga menghasilkan Declaration of Independence tahun 1776 dan The Us Bill of Right tahun 1791. Perancis setelah revolusi akhirnya menghasilkan Declaration of The Right of Man and Citizens pada tahun 1789(Jengis, 2012).Dalam The Bill of Rights (Piagam Hak-Hak) yang memuat sepuluh amandemen terhadap Undang-Undang Dasar Amerika Serikat yang ditambahkan dalam tahun 1791 guna melindungi hak-hak perorangan dan negara-negara bagian dinyatakan:

1. Kongres tidak boleh membuat undang-undang mengenai suatu 
pendirian agama, atau melarang kebebasan beragama tersebut; atau mengurangi kebijakan berbicara atau kebebasan pers atau hak rakyat untuk secara damai berkumpul dan mengajukan petisi kepada pemerintah guna diselesaikan keluhan-keluhan.

2. Sebuah angkatan bersenjata yang teratur baik, karena diperlukan demi keamanan sebuah negara yang bebas, hak rakyat untuk menyimpan dan membawa senjata api tidak boleh dilanggar.

3. Tidak ada prajurit di masa damai boleh menginap di sembarang rumah, tanpa persetujuan pemiliknya dan di waktu perang juga selain dengan cara yang telah ditentukan oleh undang-undang.

4. Hak rakyat untuk merasa aman mengenai diri pribadinya, rumah, surat dan surat-surat berharga miliknya, terhadap pengeladahan dan penyitaan yang tidak beralasan tidak boleh dilanggar.

5. Tidak ada orang yang ditahan untuk menjawab suatu kejahatan yang besar, atau kejahatan lain yang hina, selain atas penyajian atau tuduhan suatu dewan juri dan tak ada seorangpun boleh dituduh melakukan pelanggaran yang sama bahkan nyawa ataupun anggota badannya dua kali, dan diapun tidak boleh dipaksa dalam kasus pidana apapun untuk menjadi saksi melawan dirinya sendiri, atau dirampas kehidupan, kebebasan, atau harta bendanya, tanpa proses hukum yang wajar, dan harta milik perorangan tidak boleh diambil untuk kepentingan umum tanpa ganti rugi yang adil.

6. Dalam semua pengadilan pidana, tertuduh harus mendapatkan hak untuk diadili secara cepat dan terbuka, oleh suatu juri negara bagian dan distrik yang tidak memihak tempat terjadinya kejahatan tersebut, distrik mana harus sudah ditentukan sebelumnya oleh undang-undang dan diberitahukan tentang sifat dan sebab dakwaannya; hak untuk dihadapkan dengan saksi-saksi terhadapnya; hak untuk mendapatkan proses wajib guna memperoleh saksi-saksi yang meringankan dan hak untuk mendapatkan pengacara untuk membelanya.

7. Dalam tuntutan-tuntutan hukum biasa, di mana nilai yang dipertentangkan di atas \$20, hak untuk diadili oleh juri harus dipertahankan.

8. Tidak boleh ada uang tebusan yang terlampau berat, demikian juga denda yang terlampau tinggi tidak boleh ditimpakan, demikian pula tidak boleh memberikan hukuman kejam dan tidak biasa.

9. Perincian dalam kontsitusi terhadap hak-hak tertentu tidak boleh disusun guna meremehkan hak-hak lain yang tetap dimiliki oleh rakyat.

10. Wewenang-wewenang yang tidak dilimpahkan kepada Amerika Serikat oleh Undang-Undang Dasar dan tidak dilarang oleh undangundang itu bagi negara-negara bagian, tetap dipertahankan bagi masing-masing negara bagian, atau bagi rakyat(George Clack dan Kathleen Hug, 1998).

Dalam Deklarasi Universal HAM (DUHAM) yang dikukuhkan oleh PBB dalam Universal Declaration of Human Right (UDHR) pada tahun 1948. Menurut Universal Declaration of Human Right, terdapat lima jenis hak 
asasi yang dimiliki oleh setiap individu : 1) Hak personal (hak jaminan kebutuhan pribadi); 2) Hak legal (hak jaminan perlindungan hukum); 3) Hak sipil dan politik; 4) Hak subsistensi (hak jaminan adanya sumber daya untuk menunjang kehidupan); dan 5) Hak ekonomi, sosial, dan budaya (Radjawane, 2014). Selanjutnya Pieter Radjawane menjelaskan bahwa tidak semua constitusional rights itu identik dengan hak asasi manusia (human rights), karena ada juga hak-hak konstitusional warga negara yang bukan atau tidak termasuk ke dalam pengertian hak asasi manusia. Pemerintahan Indonesia menyambut baik gagasan HAM yang digaungkan di tingkat Internasional dengan dibentuknya Komisi Nasional Hak Asasi Manusia (Komnas HAM) dengan Keputusan Presiden Nomor 50 Tahun 1993. Sejak 1999, keberadaan Komnas HAM didasarkan pada Undang-Undang nomor 39 tahun 1999 yang juga menetapkan keberadaan, tujuan, fungsi, keanggotaan, asas, kelengkapan serta tugas dan wewenang Komnas HAM. Disamping kewenangan tersebut, menurut UU No. 39 Tahun 1999, Komnas HAM juga berwenang melakukan penyelidikan terhadap pelanggaran hak asasi manusia yang berat dengan dikeluarkannya UU No. 26 Tahun 2000 tentang Pengadilan HAM. Berdasarkan Undang-undang No. 26/2000 tentang Pengadilan Hak Asasi Manusia, Komnas HAM adalah lembaga yang berwenang menyelidiki pelanggaran hak asasi manusia yang berat. Dalam melakukan penyelidikan ini Komnas HAM dapat membentuk tim ad hoc yang terdiri atas Komisi Hak Asasi Manusia dan unsur masyarakat. Komnas HAM berdasarkan UndangUndang Nomor 40 Tahun 2008 tentang
Penghapusan Diskriminasi Ras dan Etnis, mendapatkan tambahan kewenangan berupa Pengawasan. Dimana Pengawasan adalah serangkaian tindakan yang dilakukan oleh Komnas HAM dengan maksud untuk mengevaluasi kebijakan pemerintah baik pusat maupun daerah yang dilakukan secara berkala atau insidentil dengan cara memantau, mencari fakta, menilai guna mencari dan menemukan ada tidaknya diskriminasi ras dan etnis yang ditindaklanjuti dengan rekomendasi (Radjawane, 2014).

Al-Qur'an juga mengakui akan adanya hak manusia yang mesti dihormati. Dari penelusuran penulis ditemukan beberapa contoh ayat yang berkaitan erat dengan hak manusia, misalnya:

Hak Untuk Hidup, Q.S. al-An'âm/6: 151:

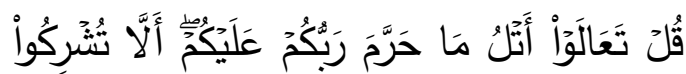

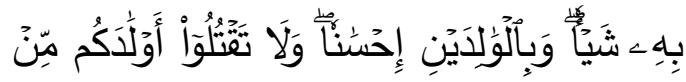

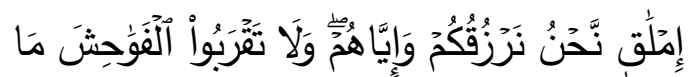

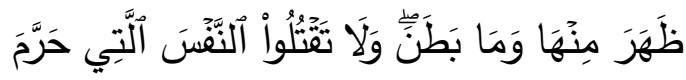

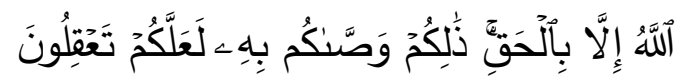
Katakanlah (Muhammad), "Marilah aku bacakan apa yang diharamkan Tuhan kepadamu. Jangan mempersekutukan-Nya dengan apa pun, berbuat baik kepada ibu bapak, janganlah membunuh anak-anakmu karena miskin. Kamilah yang memberi rezeki kepadamu dan kepada mereka; janganlah kamu mendekati perbuatan yang keji, baik yang terlihat ataupun yang tersembunyi, janganlah kamu membunuh orang yang diharamkan Allah kecuali dengan alasan yang 
benar. Demikianlah Dia memerintahkan kepadamu agar kamu mengerti.

Hak Untuk Memeluk Agama, Q.S. alBaqarah/2: 256:

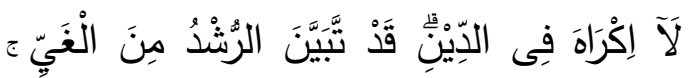

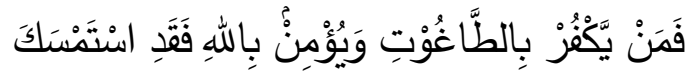

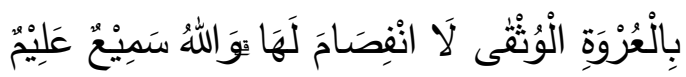
Tidak ada paksaan dalam (menganut) agama (Islam), sesungguhnya telah jelas (perbedaan) antara jalan yang benar dengan jalan yang sesat. Barang siapa ingkar kepada Tagut dan beriman kepada Allah, maka sungguh, dia telah berpegang (teguh) pada tali yang sangat kuat yang tidak akan putus. Allah Maha Mendengar, Maha Mengetahui.

Hak Untuk Mendapatkan Keadilan, Q.S. Surah an-Nisâ'/4:58:

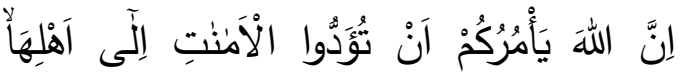

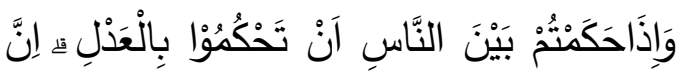

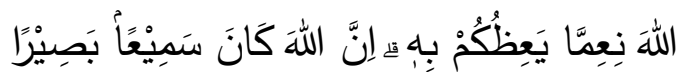
Sungguh, Allah menyuruhmu menyampaikan amanat kepada yang berhak menerimanya, dan apabila kamu menetapkan hukum di antara manusia hendaknya kamu menetapkannya dengan adil. Sungguh, Allah sebaikbaik yang memberi pengajaran kepadamu. Sungguh, Allah Maha Mendengar, Maha Melihat.

Menariknya, pembahasan HAM perspektif al-Qur'an jika didekati dengan konsep maqashid as-syarî'ah akan menjadi bukti kuat bahwa Islam adalah agama yang sangat memuliakan manusia, bukan agama yang menyukai pembunuhan, merampas harta pemeluk agama lain atau agama yang menempatkan perempuan di bawah posisi laki-laki sebagaimana yang sering dituduhkan. Tulisan ini mencoba mematahkan anggapan-anggapan berbagai pihak yang keliru tentang Islam sekaligus membuktikan betapa Islam mengajarkan kepada umatnya untuk menghargai sesama manusia.

\section{PEMBAHASAN}

\section{Perbincangan HAM dalam Konteks} Agama Islam dan Katolik

Hak Asasi Manusia

(HAM)merupakan hak yang secara alamiah diperoleh seseorang sejak lahir, HAM sangat sejalan dengan ftrah yang pada hakikatnya merupakan anugerah Allah swt. kepada semua manusia. HAM yang melekat pada diri manusia, bersifat kodrati, universal, dan abadi berkaitan dengan martabat dan harkat manusia itu sendiri (Suhaili, 2019). Menurut Jan Meterson dari Komisi HAM PBB bahwa hak asasi manusia adalah hak-hak yang melekat pada setiap manusia, yang tanpa hak tersebut manusia mustahil dapat hidup sebagai manusia. Hak tersebut adalah hak yang dibawa sejak lahir sebagai anugerah Tuhan Yang Maha Esa bukan pemberian manusia atau penguasa. Hak ini sifatnya sangat mendasar bagi hidup dan kehidupan manusia yang bersifat kodrati, yakni ia tidak dapat terlepas dari dan dalam kehidupan manusia (Alfaruqi, 2017).

Secara umum, hak manusia terbagi 2: 1) hak yang telah disediakan Tuhan dengan sedemikian rupa, sehingga manusia dapat menikmatinya langsung, 2) hak yang harus diupayakan oleh manusia untuk mewujudkannya. Apabila dengan usahanya itu ia tidak berhasil mendapatkan haknya, maka kewajiban pihak lain untuk membantu sehingga ia mendapatkan atau 
menikmati haknya(Hidayatullah, 1992). Pada prinsipnya, tidak ada hak yang istimewa yang diberikan Tuhan kepada manusia, tidak ada kelebihan yang diberikan kepada orang Arab dengan yang bukan Arab, tidak ada kelebihan orang yang berkulit putih dari yang berkulit hitam. Kendati demikian, Islam tidak mengingkari adanya perbedaanperbedaan situasi dan kondisi yang dialami umat manusia sehingga berbeda pula taraf aktualisasi kemampuankemampuan yang mereka miliki untuk memikul tanggung jawab mewujudkan hak-hak yang dibutuhkan. Kemampuan yang dimiliki seseorang harus dikembangkan semaksimal dan sebaik mungkin dalam mewujudkan hak yang dibutuhkannya itu. Banyak bukti di dunia bahwa orang berhasil mendapatkan haknya setelah menunaikan tanggung jawabnya dengan baik, dan orang gagal mendapatkan haknya karena tidak menunaikan kewajibannya. Juga banyak bukti bahwa sebagian orang gagal mendapatkan haknya, kendati sudah menunaikan tanggung jawab dengan baik, dan banyak pula yang mendapatkan dengan jalan yang mungkar. Karena di dunia tidak terlaksana keadilan dengan sempurna antara memperoleh hak yang wajar dan penunaian tanggung jawab, maka di hari pembalasan yang adil (akhirat) merupakan hak yang dibutuhkan keberadaannya (Hidayatullah, 1992).

Hakikat Hak Asasi Manusia merupakan upaya menjaga keselamatan eksistensi manusia secara utuh melalui aksi keseimbangan antara kepentingan perseorangan dengan kepentingan umum. Begitu juga upaya menghormati, melindungi, dan menjunjung tinggi Hak Asasi Manusia menjadi kewajiban dan tangung jawab Hak Asasi Manusia Dalam
Islam bersama antara individu, pemeritah (Aparatur Pemerintahan baik Sipil maupun Militer), dan negara. Berdasarkan beberapa rumusan hak asasi manusia di atas, dapat ditarik kesimpulan tentang beberapa sisi pokok hakikat hak asasi manusia, yaitu:

a. HAM tidak perlu diberikan, dibeli ataupun diwarisi, HAM adalah bagian dari manusia secara otomatis.

b. HAM berlaku untuk semua orang tanpa memandang jenis kelamin, ras, agama, etnis, pandangan politik atau asal usul sosial, dan bangsa.

c. HAM tidak bisa dilanggar, tidak seorangpun mempunyai hak untuk membatasi atau melanggar hak orang lain. Orang tetap mempunyai HAM walaupun sebuah negara membuat hukum yang tidak melindungi atau melanggar HAM (Hafniati, 2018).

Issu HAM tidak hanya menjadi perbincangan hangat dikalangan filosof, para pejuang HAM atau lainnya. Tetapi perbincangan HAM juga hangat dibahas di lingkungan tokoh-tokoh agama besar di dunia. Di antara agama-agama yang membicarakan HAM adalah sebagai berikut:

\section{HAM dalam Pandangan Agama Islam}

Menurut Masdar F. Mas'udi pada umumnya diskursus HAM masih merupakan barang baru. Beberapa waktu belakangan, Perhimpunan Pesantren dan Pengembangan Masyarakat (P3M) melakukan pertemuan-pertemuan dengan kalangan kyai muda yang mampu merefleksikan HAM. HAM baru ditemukan dalam literatur-literatur mutakhir, yang ditulis oleh sarjana muslim dan kaum terpelajar setelah mereka memiliki kontak intelektual dengan dunia Barat, seperti 
Falid Muhamad dan Abdullah an-Naim. Abdullah an-Naim adalah seorang murid Mahmoud Mohamed Thaha, yang amat baik menterjemahkan pikiran gurunya, dengan tawaran metodologi pemahaman keagamaan yang baru dan kontroversial sampai-sampai ia sendiri menjadi korban pelaggaran HAM. Ia mati di tiang gantungan pada pemerintahan Hasan Numairi. Mohamed Thaha yang juga seorang insinyur belajar keagamaan dari keilmuan Islam konvensional, sementara untuk HAM, dia belajar di Barat, Abdullah an-Naim juga memperdalam pengetahuan HAM di Barat.Dalam kitab-kitab fiqh, populer akan adanya 5 HAM yaitu: 1) hak perlindungan terhadap jiwa atau hak hidup, 2) perlindungan keyakinan, 3) perlindungan terhadap akal pikiran, 4) perlindungan terhadap hak milik dan 5) hak bekeluarga atau hak memperoleh keturunan dan mempertahankan nama baik (Mardiniah, 2000). Selain pengakuan akan 5 hak di atas, hak bekerja dan mendapatkan upah, Hak persamaan dan keadilan, dan Hak kebebasan berpendapat serta Hak atas jaminan sosial. Termasuk hak yang diakui dalam Islam (Nur Asiah, 2017).

Kesadaran akan pentingnya menempatkan manusia sebagai titik sentral pembangunan (human centred development) muncul bersamaan dengan kesadaran akan pentingnya penghargaan terhadap sesama manusia dan kesadaran pentingnya HAM. Dalam Islam manusia memiliki peran dan kedudukan yang begitu mulia. Sebagai khalifah manusia diberi tanggung jawab dan wewenang untuk memakmurkan bumi, mengolah dan memanfaatkan alam dengan sebaik-baiknya demi kemaslahatan dan kemakmuran bersama. Konsep HAM dalam Islam berakar pada penghormatan yang tinggi kepada manusia sebagai makhluk yang berharga dan menempatkannya sebagai subyek bukan obyek. Manusia adalah makhluk yang harus dihormati tanpa memandang jenis kelamin, ras, bangsa, dan agama, di hadapan Allah semua manusia sama, yang membedakannya hanya ketakwaannya (surah alHujurât/49:13). Ini sejalan dengan prinsip-prinsip universal HAM yang mengajarkan persamaan dan kebebasan sehingga manusia harus dimanusiakan, tidak boleh ada diskriminasi,eksploitasi, dan kekerasan terhadap manusia. Kebebasan dasar manusia harus dihargai dan dilindungi (Mukhoyyaroh, 2019).

Majelis Ulama Indoensia (MUI) mengeluarkan Fatwa tentang HAM: Wajib menerima, menghormati dan menjunjung tinggi hak-hak asasi manusia yang bersifat universal dengan syarat:

1) Menghargai dan menghormati perbedaan pemahaman, penafsiran serta pelaksanaan yang didasarkan oleh perbedaan budaya, kesusilaan, dan perundang-undangan yang berlaku di negara masing-masing.

2) Pemahaman dan pelaksanaan HAM wajib memperhatikan:

a) Keseimbangan antara hak individu dan kewajiban individu;

b) Keseimbangan antara hak individu dan hak masyarakat,

c) Keseimbangan antara hak kebebasan dan tanggung jawab.

3) Berkenaan dengan pasal 16 ayat $1 \& 2$ dan pasal 18 Universal 
Declaration of Human Right di mana umat Islam wajib berpegang teguh pada ajaran Islam, karena kebebasan mengamalkan ajaran agama adalah bagian dari HAM.

4) Mewajibkan kepada pemerintah dan umat Islam,terutama tokohtokohnya memasyarakatkan HAM yang sesuai dengan nilainilai agama, budaya dan tata susila masyarakat, serta perundang-undangan yang berlaku di negara Indonesia (Majelis Ulama Indonesia, 2000).

Nabi Saw.telah meletakkan dasardasar HAMyang juga dikenal sebagai Konstitusi Negara pertama di dunia yang tertuang dalam Piagam Madinah di antaranya:

Pasal 2-10 Terkait Keadilan dan Kesamaan di Mata Hukum

Pasal 2:

المهاجرون من قر يش على ربعتهم يتعاقلون بينهم اخذالدية واعطائها وهم يفدون عانيهم بالمعروف والقسط بين المؤمنين

(kebiasaan) kaum muhajirin dari suku Quraisy mereka bahu membahu membayar diat di antara mereka dan mereka membayar tebusan tawanan dengan cara baik dan adil di antara mukminin

Pasal 3:

وبنو عوف على ربعتهم يتعاقلون معاقلهم الأولى وكل طائفة تفدى عانيها بالمعروف

$$
\text { والقسط بين المؤمنين }
$$

Banu Auf sesuai dengan keadaan (kebiasaan) mereka bahu membahu membayar diat di antara mereka seperti semula, dan setiap suku membayar tebusan tawanan dengan baik dan adil di antara mukminin

Pasal 4:

وبنو ساعدة على ربعتهم يتعاقلون معاقلهم الأولى وكل طائفة منهم تفدى عانيها بالمعروف والقسط بين المؤمنين

Banu Sa'idah sesuai dengan keadaan (kebiasaan) mereka bahu membahu membayar diat di antara mereka seperti semula, dan setiap suku membayar tebusan tawanan dengan baik dan adil di antara mukminin.

Pasal 14 Terkait Hak untuk Hidup

ولا يقتل مؤهن مؤمنا فى كافر ولا ينصر كافرا على مؤمن

Seorang mukmin tidak boleh membunuh orang beriman lainnya lantaran membunuh orang kafir. Tidak boleh pula orang beriman membantu orang kafir untuk (membunuh) orang beriman.

Pasal 16 tentang Hak Mendapat Santunan

وانه من تبعنا من يهود فإن له النصر والاسوة

$$
\text { غير مظلومين ولا متناصر عليهح }
$$

Sesungguhnya orang Yahudi yang mengikuti kita berhak atas pertolongan dan santunan, sepanjang (mukminin) tidak terzalimi dan ditentang olehnya

Pasal 25 tentang Hak Kebebasan Beragama

وان يهود بني عوف أمة مع المؤمنين لليهود دينهم وللمسلمين دينهم مواليهم وأنفسهم إلا من ظلم وإثم فإنه لا يوتخ إلا نفسه وأهل بيته 
Kaum Yahudi dari Bani 'Awf adalah satu umat dengan mukminin. Bagi kaum Yahudi agama mereka, dan bagi kaum muslimin agama mereka. Juga (kebebasan ini berlaku) bagi sekutusekutu dan diri mereka sendiri, kecuali bagi yang zalim dan jahat. Hal demikian akan merusak diri dan keluar (Zariq, 1996).

Dari beberapa pasal yang dikutip dari Piagam Madinah di atas terlihat bahwa Nabi Saw. Sangat menghargai, memberikan toleransi dan bahkan melindungi umat-umat yang bukan pemeluk agama Islam. Dan dalam Piagam Madinah juga sudah muncul pengakuan akan adanya asas persamaan di antara manusia di mana masingmasing anggota masyarakat harus saling menghormati, menghargai dan melindungi satu sama lainnya,baik menyangkut persoalan keyakinan, harta maupun kehidupan.

\section{HAM dari Sudut Pandang Teologi Katolik}

Paus Johannes XXIII (di pertengahan abad ke-20) memberikan uraian sistem katolik yang cukup luas dalam suratnya yang berjudul "Damai di Bumi" (Pacem in Terria). Dalam suratnya itu Johannes XXIII menyebut HAM sebagai jaminan agar manusia melaksanakan tindakan-tindakan manusia yang ciri khasnya: mandiri, tahu dan mau. Pada umumnya hukum, kodrat dianggap meliputi hak akan hidup, hak untuk nilai-niai moral dan kultur tertentu, hak untuk berpartisipasi dalam hidup sosial, hak untuk bebas melaksanakan agamanya, hak untuk memilih status hidupnya, hak untuk ekonomi dan beremigrasi dan imigrasi, dan hak untuk mendapatkan perlindungan legal atas hak-haknya.
Paus Paulus VI dalam Gravisium Education, bersama para Bapa Konsili Vatikan II berusaha untuk menegaskan hak asasi orang tua untuk mendidik anak-anak mereka (GE3). Kecuali itu, masyarakat juga mempunyai pula hak untuk menyelenggarakan pendidikan: bukan karena diberi oleh negara. Dalam Synode tahun 1974 para uskup sedunia sepakat berpendapat, bahwa pengakuan HAM yang dapat memulihkan hubungan antar bangsa dan antar golongan dalam negara-negara. Gereja menganggap perlindungan hak pribadi manusia sebagai tugas mulia dan menolak diskriminasi dalam bentuk apapun (Mardiniah, 2000).

\section{HAM dalam Tinjauan Maqâshid asy- Syârî'ah}

Sitti Aminah menjelaskan bahwa HAM dalam al-Qur'an bisa dibedakan kepada: 1) HAM bersifat individual, yang meliputi hak untuk hidup dan hak untuk memeluk agama. 2) Hak Memperoleh Kemerdekaan, 3) HAM yang Bersifat Sosial berupa persamaan derajat kemanusiaan.(Aminah, 2010). Paparan lebih luas tentang hak asasi yang mesti didapatkan oleh setiap warga negara berdasarkan petunjuk-petunjuk ajaran Islam dijelaskan oleh Umar Shihab (Umar Shihab, 2005) dan oleh Akhmad Jengis (Jengis, 2012)sebagai berikut:

\section{Hak Hidup}

Setiap manusia berhak untuk hidup layak, aman, damai, dan bahagia. Tidak berhak merampasnya, kecuali berdasarkan kebenaran dan ketentuan dari Allah itu sendiri.Terdapat beberapa ayat al-Qur'an yang menyuruh kepada manusia untuk menjamin keselamatan jiwa sesamanya, yaitu: 
1) Surah al-Hijr/15: 23: tentang kewenangan untuk menghidupkan dan mematikan manusia hanyalah kewenangan Allah, dengan katalain manusia sama sekali tidak berhak menghilangkan hak hidup seseorang dengan membunuhnya.

2) Surah Al-An'am/6: 151: terkait peringatan agar manusia tidak membunuh manusia lain yang tidak bersalah, kebolehan membunuh seseorang harus berdasarkan keputusan hakim dalam suatu pengadilan yang kompeten.

3) Q.S.Al-Maidah/5 32:usaha menyelamatkan jiwa sesama manusia merupakan suatu kewajiban. Apapun bangsa, ras, dan warna kulitnya, bilamana dia membutuhkan pertolongan atau jiwanya terancam.

4) Surah an-Nisa'/4:29: manusia juga berkewajiban menyelamatkan dirinya sendiri dari berbagai bahaya yang puncaknya menyebabkan kematian.

5) Surah al-Isra'/17: 31: Larangan membunuh anak-anak dengan berbagai alasan yang tidak dibenarkan.

Ajaran Islam memberikan jaminan sepenuhnya bagi setiap manusia untuk mendapatkan hak hidup, kecuali jika ada alasan yang dibenarkan hukum syara'. Prinsip itu antara lain, dijelaskan dalam Surah al-An`am/6: 151:

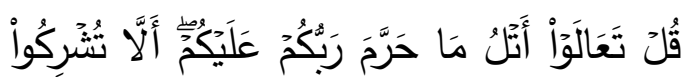

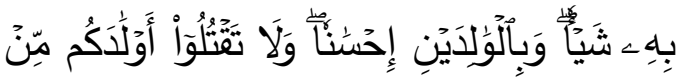

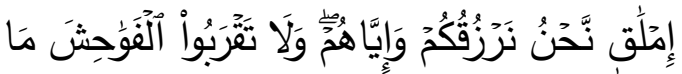

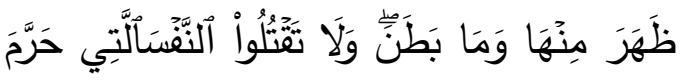

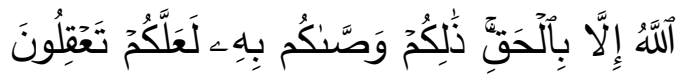

\section{1}

Katakanlah: "Marilah kubacakan apa yang diharamkan atas kamu oleh Tuhanmu yaitu: janganlah kamu mempersekutukan sesuatu dengan Dia, berbuat baiklah terhadap kedua orang ibu bapa, dan janganlah kamu membunuh anak-anak kamu karena takut kemiskinan, Kami akan memberi rezeki kepadamu dan kepada mereka, dan janganlah kamu mendekati perbuatan-perbuatan yang keji, baik yang nampak di antaranya maupun yang tersembunyi, dan janganlah kamu membunuh jiwa yang diharamkan Allah (membunuhnya) melainkan dengan sesuatu (sebab) yang benar". Demikian itu yang diperintahkan kepadamu supaya kamu memahami(nya) (alAn`am/6: 151).

Larangan membunuh bukan sesuatu yang baru, tetapi merupakan syari'at seluruh agama sejak kelahiran manusia di muka bumi. Kata harrama yang dikaitkan dengan jiwa manusia oleh ayat di atas dipahami dalam arti yang dijadikan terhormat oleh Allah. Pemahaman seperti ini juga mendukung nilai-nilai asasi manusia yang juga merupakan salah satu prinsip kehidupan yang ditegakkan al-Qur'an melalui sekian ayat (Shihab, 2002). Allah memberi hak hidup bagi segala jiwa. Sebab itu janganlah kamu membunuh orang. Sejak dari anak yang masih dalam kandungan tetapi telah ada nyawa sampai orang tua yang telah dekat sampai ajalnya. Termasuk membunuh diri sendiri, sebab nyawa sendiri itupun mendapat hak yang langsung dari Allah buat hidup. Disebut di sini "kecuali dengan hak" yaitu mencabut nyawa seseorang hanya boleh apabila ada hak 
hakim untuk membunuhnya karena dia merugikan masyarakat, tegasnya karena dia telah salah memakai hak hidup yang diberikan Tuhan kepadanya. Karena dia telah membunuh orang lain, atau merusakkan keamanan, atau memerangi Allah dan rasulNya, sebagai hukuman yang disebut di dalam Surah alMaidah/5:32-33. Termasuk juga "kecuali dengan hak" ialah pembunuhan-pembunuhan yang terjadi dalam peperangan, dengan syarat-syarat yang tertentu pula (HAMKA, 1983).

Bahkan syariat Islam menetapkan adanya hak seorang Muslim yang dapat dituntutnya atas saudaranya sesama Muslim, dalam rangka menyelamatkan hidupnya. Ini berarti bahwa seorang muslim wajib bertindak aktif membantu saudaranya yang terancam jiwanya.Dalam hubungan ini M.Timur menyatakan bahwa dalam keadaankeadaan tertentu seseorang berkewajiban memberikan bantuan positif untuk menyelamatkan hak saudaranya. Sebagai contoh, jika hak tersebut adalah hak seseorang untuk hidup, maka masyarakat tidak saja berkewajiban untuk tidak membunuhnya, tetapi juga berkewajiban untuk menyediakan lapangan kerja baginya. Dan segala hal yang bersangkutan untuk kelanjutan hidup adalah wajib dilaksanakan, misalnya menjaga kesehatan umum. Segala yang membahayakan jiwa atau merusak jasmani, membahayakan atau melemahkan jiwa adalah haram. Segala yang dapat mencegah orang dari kematian harus dilakukan dan wajib dilakukan kalau dianggap hanya dengan itu saja kematian dapat dicegah (Rusjdi Ali Muhammad, 2004).

Untuk mejamin pelaksanaan hak hidup ini ajaran Islam tidak hanya mencukupkan pada tanggung jawab moral atau ancaman siksaan akhirat semata-mata. Tetapi syariat Islam menetapkan pula berbagai ketentuan hukum untuk menjamin pelaksanaan secara nyata. Di antara aturan tersebut adalah: Penetapan hukuman qishas bagi tindak pembunuhan sengaja. Firman Allah dalam Surah al-Baqarah/2:178:

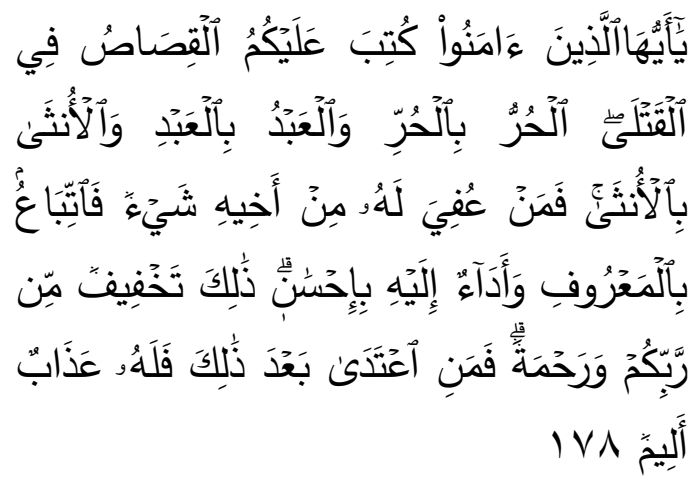

Hai orang-orang yang beriman, diwajibkan atas kamu qishaash berkenaan dengan orang-orang yang dibunuh; orang merdeka dengan orang merdeka, hamba dengan hamba, dan wanita dengan wanita. Maka barangsiapa yang mendapat suatu pemaafan dari saudaranya, hendaklah (yang memaafkan) mengikuti dengan cara yang baik, dan hendaklah (yang diberi maaf) membayar (diat) kepada yang memberi maaf dengan cara yang baik (pula). Yang demikian itu adalah suatu keringanan dari Tuhan kamu dan suatu rahmat. Barangsiapa yang melampaui batas sesudah itu, maka baginya siksa yang sangat pedih (alBaqarah/2:178).

Sebelum Islam, hukuman pembunuhan bermacam-macam, di kalangan kaum Yahudi, hukuman pembunuhan adalah qishas, sedangkan di kalangan kaum Nasrani hukumannya adalah diat. Sementara dikalangan bangsa Arab Jahiliyah berkembang kebiasaan balas dendam: yang dibunuh 
adalah selain si pembunuh, kadang mereka bahkan membunuh si kepala suku atau membunuh lebih dari satu orang dari suku si pembunuh. Kemudian, sebagai bentuk aplikasi keadilan dan persamaan, Islam menetapkan hukuman qishas karena hukuman ini akan mencegah manusia melakukan tindak kejahatan berupa pembunuhan. Hukuman ini masih menjadi satu-satunya hukuman yang efektif di zaman sekarang (Wahbah alZuhaily, 2009a).

\section{Hak Beragama}

Negara seyogyanya memberikan kebebasan kepada seseorang untuk memeluk agama yang diyakininya, di antara ayat-ayat al-Qur'an yang berbicara tentang kebebasan beragama adalah:

1) Al-Bayyinah/98: 5: Beragama harus didasarkan pada kepatuhan yang tulus kepada Allah.

2) Al-Baqarah/2: 256: Memuat pernyataan tidak ada paksaan dalam menganut agama.

3) Al-Ankabut/29: 18: kewajiban para rasul dan para penganjur-penganjur agama Islam hanya menyampaikan.

4) Al-Isra'/17: 106-107: Manusia dipersilahkan mengambil sikap terkait aspek keyakinannya.

Selain makhluk sosial, manusia adalah makhluk beragama. Status ini meniscayakan manusia untuk percaya kepada Tuhan. Beribadah merupakan aspek penting dalam keberagamaan seseorang, karena penghormatannya atas keberadaan dan tata cara ibadah agama lain adalah penting. Islam menanamkan prinsip umum terkait sikap keberagamaan seseorang,yaitu "tidak ada paksaan dalam agama,"
(Lajnah Pentashihan Mushaf al-Qur'an, 2010)seperti dalam firman Allah dalam surah al-Baqarah/2: 256:

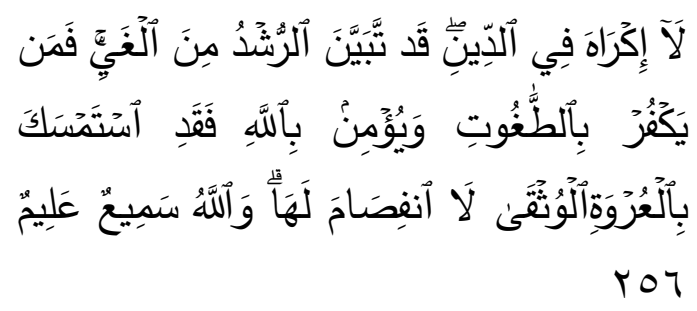

Tidak ada paksaan untuk (memasuki) agama (Islam); sesungguhnya telah jelas jalan yang benar daripada jalan yang sesat. Karena itu barangsiapa yang ingkar kepada Thaghut dan beriman kepada Allah, maka sesungguhnya ia telah berpegang kepada buhul tali yang amat kuat yang tidak akan putus. Dan Allah Maha Mendengar lagi Maha Mengetahui (alBaqarah:256).

Dalam ayat ini, arti petunjuk diartikan dengan redaksi ar-rusyd yang mulanya berarti kecerdasan dan kedewasaan. Namun, meskipun paksaan dalam memeluk agama telah dinafikan, akan tetapi manusia akan cenderung memilih agama yang benar jika ia memiliki kecerdasan dan kedewasaan berfikir. Dengan demikian, kebebasan beragama sejatinya adalah bentuk penghormatan Allah terhadap manusia yang paling baik dan sempurna sekaligus sebagai realisasi atas karakterisitik manusia sebagai makhluk yang bertanggung jawab. Kebebasan memilih agama merupakan hak asasi manusia yang dilindungi hukum. Pasal 18 Deklarasi Universal HAM menyatakan "setiap orang berhak untuk bebas berfikir, bertobat, dan beragama. Hak ini meliputi kebebasan berganti agama atau kepercayaan dan kebebasan menyatakan agama atau kepercayaan dalam bentuk beribadah dan 
menepatinya, baik secara sendiri maupun dilakukan bersama dengan orang lain, di tempat umum maupun tempat privat (Lajnah Pentashihan Mushaf al-Qur'an, 2010).

\section{Hak Untuk Mendapatkan Pendidikan}

Salah satu hak dari hak asasi manusia adalah hak untuk memperoleh pendidikan. Tak seorangpun dapat dibatasi haknya untuk belajar dan mendapatkan pengetahuan dan pendidikan, sepanjang ia memenuhi kualifikasi untuk itu (Rusjdi Ali Muhammad, 2004). Menurut Hasbi Ash-Shiddieqy, ajaran Islam tidak hanya menegakkan sendi kemerdekaan belajar, lebih dari itu Islam mewajibkan semua orang Islam untuk menuntut pelajaran. Sebab ajaran Islam didatangkan untuk memerdekakan akal (Rusjdi Ali Muhammad, 2004). Islam membuka pintu ilmu pengetahuan dan menganjurkan kepada manusia untuk mendalaminya, dan untuk maju. Umat Islam dipersilakan untuk menerima ilmu-ilmu baru sesuai dengan perkembangan zaman (Bakar Musa, 1988). Dalam al-Qur'an ditemukan beberapa isyarat untuk memuliakan akal dan memanfaatkannya, di antaranya Surah al-Taubah/9:22:

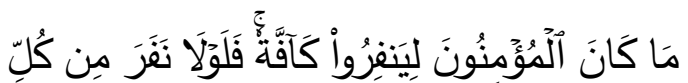

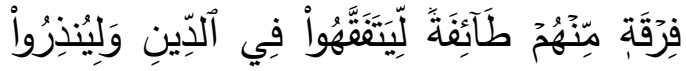

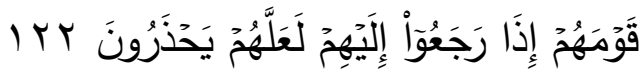

Tidak sepatutnya bagi mukminin itu pergi semuanya (ke medan perang). Mengapa tidak pergi dari tiap-tiap golongan di antara mereka beberapa orang untuk memperdalam pengetahuan mereka tentang agama dan untuk memberi peringatan kepada kaumnya apabila mereka telah kembali kepadanya, supaya mereka itu dapat menjaga dirinya (al-Taubah/9:22).

Allah menerangkan bahwa tidak semua mukmin harus berangkat ke medan perang,bila peperangan itu dapat dilakukan oleh sebagian kaum Muslimin saja. Tetapi harus ada pembagian tugas dalam masyarakat, sebagian berangkat perang, dan sebagian lagi harus menuntut ilmu dan mendalami Islam, supaya ajara-ajaran agama itu dapat diajarkan secara merata, dan dakwah dapat dilakukan dengan cara efektif dan bermanfaat sehingga kecerdasan umat Islam dapat ditingkatkan(Kemeterian Agama RI, 2010). Allah menjanjikan kehidupan yang lebih baik dan lebih layak bagi orang-orang yang memiliki pengetahuan dalam Surah alMujâdilah/58/11:

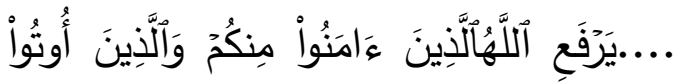

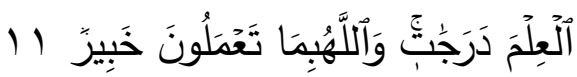
...niscaya Allah akan meninggikan orang-orang yang beriman di antaramu dan orang-orang yang diberi ilmu pengetahuan beberapa derajat. Dan Allah Maha Mengetahui apa yang kamu kerjakan (Surah al-Mujadilah/58/11).

Dalam menafsirkan ayat ini, Wahbah al-Zuhaily menjelaskan baahwa Allah telah meninggikan dan memuliakan para ulama dan orangorang berilmu di antara mereka secara khusus beberapa derajat dari sisi kehormatan dan kemuliaannya. Karena para ulama itu menggabungkan antara ilmu dan amal. sebab, ilmu sendiri di samping tinggi dan luhur kedudukannya (Wahbah al-Zuhaily, 2009b).

Dalam hubungan ini, wawasan egalitarinisme Islam dengan jelas 
terlihat dalam kesempatan yang sama dan terbuka kepada setiap orang untuk memilih dan mengembangkan bidangbidang ilmu pengetahuan yang dinilainya sesuai untuk dirinya. Dalam Islam tidak ada bagian ilmu pengetahuan tertutup yang hanya dapat dipelajari oleh orang-orang atau golongan-golongan tertentu saja. Tidak pula dikenal profesi tertutup yang hanya dapat diduduki oleh pihak-pihak tertentu hanya karena keuntungan dalam aspek primordialnya seperti suku, ras, warna kulit,keturunan dan sebagainya. Ajaran al-Qur'an berulangkali menyatakan manusia untuk menggunakan akal sehat dan metode rasional guna mengambil pelajaran dari seluruh kejadian alam. Dalam al-Qur'an juga tercermin penghargaan penuh terhadap kebebasan berfikir dan kebebasan menentukan pilihan sebagai kodrat asasi manusia.Untuk memberantas buta huruf dan membuka cakrawala pengetahuan, Nabi Saw. menetapkan usaha mengajar putra-putri Islam di Madinah sebagai penebus diri bagi orang-orang Quraisy yang ditawan. Negarapun punya kewajiban untuk memperhatikan dan mempermudah jalan bagi warganegaranya untuk menuntut ilmu pengetahuan (Rusjdi Ali Muhammad, 2004).

\section{Hak Kepemilikan Harta}

Hak memiliki terbagi dua, yaitu; hak milik perseorangan dan hak milik umum. Milik perseorangan adalah barang-barang yang dikuasai secara penuh oleh setiap pribadi manusia, bagi masyarakat luas, wajib menghormati milik perseorangan, tidak mengganggunya dengan mencuri atau mengambil secara paksa. Dan wajib bagi pemilik supaya mempergunakan dengan sebaik-baiknya. Barang-barang yang dikatakan milik umum ialah barang yang lepas dari monopoli seseorang atau yang disebut milik-milik pemerintah, karena pemerintah mewakili rakyat(Ahmad Amin, 1975). Di antara ayat-ayat terkait hak kepemilikan warga negara tersebut ialah: a) al-Jasiyah/45: 12 tentang anjuran untuk berusaha; b) alBaqarah/2: 188; c) an-Nisa'/4: 29 tentanglarangan untuk merampas milik orang lain dan; al-Kahfi/18: 29 tentang setiap yang berusaha berhak mendapatkan ganjaran dari usahanya

Dalam upaya memenuhi kebutuhan hidup ini,manusia berjuang dan berusaha sedemikian rupa untuk mendapatkan aneka barang dan jasajasa. Upaya itulah yang disebut kegiatan ekonomi. Di situlah terjadi berbagai kegiatan ekonomi yang biasa melahirkan perbedaan, bahkan benturan kepentingan. Sebab masing-masing berusaha hendak memenuhi kebutuhannya dengan pengorbanan yang sekecil-kecilnya. Guna mengurangi bahkan sedapat mungkin menghilangkan kekacauan itu perlu adanya aturan atau tata hukum dalam masyarakat. Demikian juga dalam ekonomi, perlu adanya tata aturan atau sistem yang secara optimal dapat diharapkan membawa ketenangan dan ketentraman hidup manusia (Rusjdi Ali Muhammad, 2004).

Hak kepemilikan harta sangat dihargai dalam Islam. Allah terangterangan menyatakan bahwa alam dan seluruh isinya diciptakan untuk dimanfaatkan oleh manusia. Firman Allah: 


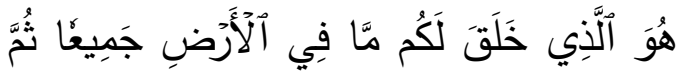

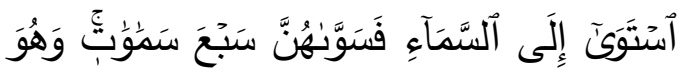

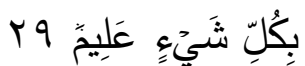

Dialah Allah, yang menjadikan segala yang ada di bumi untuk kamu dan Dia berkehendak (menciptakan) langit, lalu dijadikan-Nya tujuh langit. Dan Dia Maha Mengetahui segala sesuatu (alBaqarah:29)

Manusia diberi hak untuk mengumpulkan harta dengan cara yang benar; menikmati harta itu dan mengembangkannya dalam kebaikan. Dalam perspektif HAM, hak milik adalah hak asasi setiap manusia. Tidak ada yang berhak melarang orang lain untuk meraih dan memanfaatkan harta yang telah dicurahkan Allah di muka bumi. Dalam hukum HAM internasional, hak milik dilindungi dengan tegas. Deklarasi HAM pada pasal 17 menyatakan "setiap orang berhak mempunyai hak milik, secara privat maupun berjama'ah. Tidak seorangpun boleh mencabut hak miliknya secara sewenang-wenang." Deklarasi Universal HAM mewajibkan setiap negara untuk melindungi seluruh warga negaranya dan memberi peluang kepada mereka untuk memiliki. Negara wajib melindungi warganya dari upayaupaya pencabutan hak milik oleh sesama manusia maupun oleh negara, secara sewenang-wenang (Lajnah Pentashihan Mushaf al-Qur'an, 2010).

Harta harus diperoleh dengan jalan yang benar, dan didistribusikan di jalan yang benar pula sehingga tidak terjadi tabrakan kepentingan dan pertikaian antar sesama. Allah berfirman:

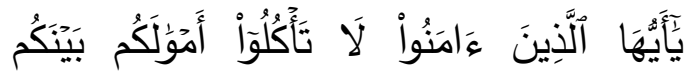

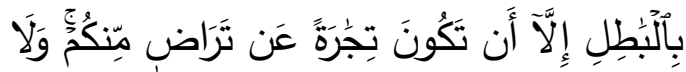

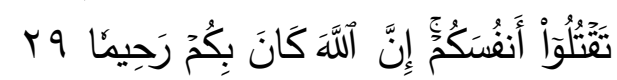
Hai orang-orang yang beriman, janganlah kamu saling memakan harta sesamamu dengan jalan yang batil, kecuali dengan jalan perniagaan yang berlaku dengan suka sama-suka di antara kamu. Dan janganlah kamu membunuh dirimu; sesungguhnya Allah adalah Maha Penyayang kepadamu (an-Nisa'/4: 29).

Dalam ayat di atas Allah melarang untuk memakan harta secara bathil. Baik harta milik sendiri maupun harta kepunyaan orang lain. Memakan harta milik sendiri berupa membelanjakan harta untuk kemaksiatan, dan memakan harta orang lain dengan cara batil meliputi segala cara yang tidak halal dalam mendapatkan harta, seperti praktek riba, pencurian dan perampokan, jual beli yang tidak sah dan sebagainya (Wahbah al-Zuhaily, 2009c).

Pasal 15 Deklarasi Kairo menjamin hak milik seseorang yang didapatkan secara sah dan benar, dengan kalimat:

1) Setiap orang berhak memiliki kekayaan dengan jalan yang sah, dan harus diberi hak untuk memiliki kekayaan tanpa prasangka bagi diri sendiri, orang lain, atau masyarakat umum. Upaya pengambilalihan secara paksa adalah tidak sah kecuali itu dilakukan untuk kepentingan umum dan dibarengi dengan pembayaran secara kontan, dan ganti rugi yang wajar.

2) Penyitaan dan perampasan hak milik adalah dilarang kecuali 
untuk suatu kepentingan yang sah berdasarkan hukum (Lajnah Pentashihan Mushaf al-Qur'an, 2010).

\section{Hak Untuk Bekeluarga}

Membina rumah tangga merupakan sifat naluriah manusia. Dengan demikian, meneruskan keturunan adalah satu dari sekian banyak hak asasi yang disandang oleh manusia. Aturan nikah dalam Islam tidak hanya membahas hal-hal yang terkait dengan urusan pasanikah,tetapi juga tidak luput dari conern-nya. Ini dapat dicermati dari firman Allah:

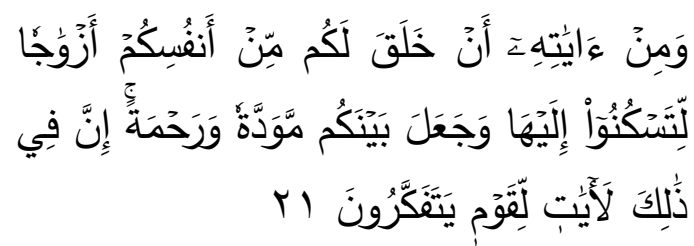

Dan di antara tanda-tanda kekuasaanNya ialah Dia menciptakan untukmu isteri-isteri dari jenismu sendiri, supaya kamu cenderung dan merasa tenteram kepadanya, dan dijadikan-Nya diantaramu rasa kasih dan sayang. Sesungguhnya pada yang demikian itu benar-benar terdapat tanda-tanda bagi kaum yang berfikir (ar-Râum/30:21).

Allah menciptakan manusia berpasangan untuk memenuhi salah satu kebutuhan manusia. Dengan adanya wanita sebagai pasangan hidup bagi laki-laki, akan mendatangkan ketentraman jiwa dan keberlangsungan species manusia akan terjamin. Pernikahan merupakan jalan yang diberikan Allah kepada manusia untuk menyalurkan naluri seksualnya dengan jalan yang benar dalam pandangan syari'at Islam (Wahbah al-Zuhaily, 2009c). Menikah dan berkeluarga merupakan hak setiap individu yang dilindungi oleh hukum. Pasal 16 Deklarasi Universal HAM menyatakan:

1) Laki-laki dan perempuan yang telah dewasa tanpa pembatasan atas perbedaan ras, bangsa, dan agama berhak untuk menikah dan membina rumah tangga. Mereka mempunya hak yang sama selama keduanya masih terikat dalam pernikahan, dan juga selama waktu perceraian.

2) Pernikahan hanya dianggap sah jika dibarengi dengan persetujuan yang bebas sepenuhnya dari kedua calon mempelai.

3) Keluarga adalah unit kelompok masyarakat yang alami dan asasi, serta berhak mendapat perlindungan dari masyarakat (Lajnah Pentashihan Mushaf alQur'an, 2010).

Syari'at Islam memiliki aturan terkait pernikahan. Para fuqahatelah merumuskan aturan-aturan pernikahan dan yang terkait dengannya, seperti laki-laki/wanita yang boleh dinikahi, saat-saat yang tidak boleh melakukan hubungan suami-isteri, aturan terkait perceraian dan sebagainya. Sebagai umat beragama, maka tentu apa yang tertuang dalam Pasal 16 Deklarasi Universal HAM perlu disikapi dengan bijak, sehingga Syari'at Islam bisa diamalkan secara totalitas tanpa mengenyampingkan HAM.

\section{PENUTUP}

Dari paparan makalah di atas, dapat disimpulkan: (a) Islam adalah agama yang sangat mendukung hak asasi manusia. (b) Untuk mendapatkan hak secara maksimal, setiap orang diharuskan berupaya dan berusaha serta memenuhi berbagai kewajibannya agar haknya bisa didapatkan secara 
sempurna. (c) Hak-hak yang dimiliki seseorang tentu dibatasi dengan hak-hak orang lain, maka di sinilah letak peran toleransi, saling menghormati dan menghargai. (d) Perlunya kajian ulang terkait hak asasi manusia secara komperehensif, karena dengan adanya aturan terkait HAM menyebabkan sebagian masyarakat tidak mendapatkan haknya. Contoh sederhana hak orang tua untuk "memarahi" anaknya menjadi terbatas dengan adanya pelarangan tindak kekerasan terhadap anak-anak. (e) Setiap pribadi muslim berkewajiban memperkenalkan HAM yang qurani ke tengah masyarakat.

\section{REFERENSI}

A. Masyhur Efendi. (1994). Dimensi Dinamika Hak Asasi Manusia dalam Hukum Nasional dan Internasional. Ghalia Indonesia.

Ahmad Amin. (1975). Etika (Ilmu Akhlak). Bulan Bintang.

Alfaruqi, D. (2017). Korelasi Hak Asasi Manusia dan Hukum Islam. SALAM: Jurnal Sosial Dan Budaya Syar-I, 4(1), 57-76. https://doi.org/10.15408/sjsbs.v4i1 .7869

Aminah, S. (2010). Hak asasi manusia (ham) dalam perspektif alquran. 8, 161-173.

Bakar Musa. (1988). Kebebasan dalam Islam. al-Ma'arif.

George Clack dan Kathleen Hug. (1998). Hak-Hak Asasi Manusia Sebuah Pengantar. Penebar Swadaya.

Hafniati. (2018). HAK ASASI MANUSIA DALAM ISLAM $\mathrm{H}$.
Al-Adyan, 13(2), 261-284. https://doi.org/http://dx.doi.org/ 10.24042/adyan.v13i2.3843

HAMKA. (1983). Tafsir al-Azhar juz 79. Pustaka Panjimas.

Hidayatullah, T. P. I. S. (1992). Ensiklopedi Islam Indonesia (p. 282). Jakarta: Djambatan.

Jengis, A. (2012). 10 Isu Global di Dunia Islam (F. Afif (ed.)). NFP Pubilishing.

John L. Esposito. (2002). EnsiklopediOxford Dunia Islam Modern, (p. 136). Bandung: Mizan.

Kementrian Agama RI. (2010). alQur'an dan Tafsirnya (Edisi yang Disempurnakan) Jilid IV. Kementrian Agama RI.

Lajnah Pentashihan Mushaf al-Qur'an. (2010). Hukum, Keadilan dan Hak Asasi Manusia (Tafsir al-Qur'an Tematik). Lajnah Pentashihan Mushaf al-Qur'an.

Majelis Ulama Indonesia. (2000). HakHak Asasi Manusia (HAM). Himpunan Fatwa MUI, 1-7.

Mardiniah, E. S. N. \& N. (2000). Diseminasi Hak Asasi Manusia. Cesda-LP3ES.

Mukhoyyaroh, M. (2019). Hak Asasi Manusia dalam Kehidupan Sosial Dalam Perspektif Al-Qur'an. Jurnal Online Studi Al-Qur An, 15(2), 219-234. https://doi.org/10.21009/jsq.015.2. 05

Musdah Mulia. (2010). Islam \& Hak Asasi Manusia Konsep dan Implementasinya. Naufan Pustaka. 
Nur Asiah. (2017). HAK ASASI MANUSIA PERSPEKTIF HUKUM ISLAM. Jurnal Syari'ah, Hukum Dan DIktum, 15(1), 55-66.

Radjawane, P. (2014). Kebebasan Beragama Sebagai Hak Konstitusi di Indonesia. Jurnal Sasi, 20(1), $30-36$.

Rusjdi Ali Muhammad. (2004). Hak Asasi Manusia dalam Perspektif Syariat Islam. Ar-Raniry Press.

Shihab, M. Q. (2002). Tafsir al-Misbah Pesan Kesan dan Keserasian alQur'an Volume IV. Lentera Hati.

Suhaili, A. (2019). Hak Asasi Manusia (HAM) Dalam Penerapan Hukum Islam Di Indonesia. Al-Bayan: Jurnal Ilmu Al-Qur'an Dan Hadist, 2(2), 176-193. https://doi.org/10.35132/albayan.v $2 \mathrm{i} 2.77$

Umar Shihab. (2005). Kontekstualitas al-Qur'an (H. M.Noer (ed.)). Penamadani.

Wahbah al-Zuhaily. (2009a). Tafsîr alMunîr fi al-Aqîdah wa al-Syarî̀'ah wa al-Minhaj Jilid 1. Dâr al-Fikr.

Wahbah al-Zuhaily. (2009b). Tafsîr alMunîr fi al-Aqîdah wa al-Syarî'ah wa al-Minhaj Jilid 14. Dâr al-Fikr.

Wahbah al-Zuhaily. (2009c). Tafsîr alMunîr fi al-Aqîdah wa al-Syarî'ah wa al-Minhaj Jilid 3. Dâr al-Fikr.

Zariq, B. (1996). No Title as-Shahifah Mitsaq ar-Rasul Dustur al-Daulah al-Islamiyah fi al-Madinah wa Awwal Dustur li Huquq alIslamiyah. Dar Ma'd. 